\title{
Toxic Potential of Papaya (Carica papaya) Leaves as Termicidal Against Coptotermes curvignathus Holmgren
}

\author{
Zahtamal $^{1}$, Syamsul A. Ardiansyah ${ }^{2}$, Titi Marsifah $^{3}$, R.C Hidayat Soesilohadi ${ }^{4}$, Setya Handayani ${ }^{5}$, and \\ Septi M. Handayani ${ }^{6}$
}

\begin{abstract}
Papaya leaf (Carica papaya) contains secondary metabolite compounds such as terpenoids, alkaloids, saponins and plavonoids. Those compounds have been known as toxic in most insects and have potential to regulate termite Coptotermes curvignathus. This research aims to analyze the potential of Carica papaya leaf as bioinsecticides and to find Lethal Concentration $\mathrm{LC}_{50}$ methanolic extract of papaya on $C$. curvignathus. The test was carried out by treating paper disc with extract at the concentration $6 \% 8 \% 10 \% \mathrm{w} / \mathrm{v}(\mathrm{g} / \mathrm{ml})$. The effect of termites has been investigated in seven days and $\mathrm{LC}_{50}$ determined by probit analyze. The bioassay showed that $\mathrm{LC}_{50}$ methanolic extract of Papaya leaf (Carica papaya) an has an effect to Coptotermes curvignathus $\mathrm{LC}_{50} 4,5 \%$.
\end{abstract}

Keywords-Coptotermes curvignathus, Methanolic extract, Mortality, Papaya leaf.

\section{INTRODUCTION}

$\mathrm{T}$ ermite belong to order Isoptera, which have been known or a destroyer to the building, and also attack the community plantation such oil palm, especially the young palm [1][2][3]. Termites play role in ecological of many ecosystems, particularly in nutrient-poor arid and semi-arid environments [4]. There are three major species of termites in Indonesia which become pests such as Coptotermes curvignathus Holmgren, Macrotermes gilvus Hagen, as well Schedorhinotermes javanicus Kemner and one type of dry wood termites, Cryptotermes cynocephalus light [5].

Zahtamal $^{1}$ Faculty of Biology, Universitas Gadjah Mada, Yogyakarta, Indonesia (phone : 085766224487 ; e-mail: zahtamal@gmail.com ).

Syamsul A. Ardiansyah ${ }^{2}$ Faculty of Biology, Universitas Gadjah Mada, Yogyakarta, Indonesia (e-mail: syamsularif2511@gmail.com).

Titi Marsifah ${ }^{3}$, Faculty of Biology, Universitas Gadjah Mada, Yogyakarta, Indonesia (e-mail: marsifahtiti@gmail.com).

Setya Handayani ${ }^{4}$, Faculty of Biology, Universitas Gadjah Mada, Yogyakarta, Indonesia (e-mail: handayani.setya@gmail.com).

Septi M. Handayani ${ }^{5}$, Faculty of Biology, Universitas Gadjah Mada, Yogyakarta, Indonesia (e-mail: septi.mutia.h@mail.ugm.ac.id).

R.C.Hidayat Soesilohadi ${ }^{6}$, Associate Profesor in Laboratory of Entomology Faculty of Biologi ,Universitas Gadjah Mada, Yogyakarta, Indonesia (e-mail: hidayat@ugm.ac.id).
Coptotermes is the only genus of sub Family Coptotermitinae spread in tropical regions [6]. The few tropical and subtropical locations where termites are found at high altitude (700-2500 m) [7][8]. Termites live in soil and remnant of wood, thus they difficult to be controlled. In there, termites can hide and breeding and find their food [9]. This insect can cause direct physical damage to crops and causing significant economic losses [10].

Nowday, the method which is used to reduce termite is insecticide that has chemical compound, such as organophosphate and pyrethroid. This compound could be harmful to the environment and animal especially insect [11][12]. An alternative that could be used as biotermicide is organic insecticide from plant such as papaya leaf [13].

Carica papaya (papaya) is a tree-like herbaceous plant [14]. Carica papaya is the member of the Family Caricaceae widely found in India, Philippines, Sri Lanka, Bangladesh, Malaysia and other countries in tropical America[15]. Recent studies said that the leaves of Carica papaya discovered compounds as a potential anti-sickling [16].

Papaya leaves contain active ingredients such as papain, chymopapain, cystatin, à-tocopherol, ascorbic acid, flavonoids, cyanogenic glucosides, and glucosinolates [17]. The contents which have potential as insecticide are papain enzyme, saponins, flavonoids and alkaloids karpain. These compounds cause many various reactions in the body of larvae which can inhibit the growth and development of them [18].

\section{MATERIAL AND METHODS}

\section{A. Time and place of research}

This research was conducted on September until February 2017. The determination of methanol extraction from papaya leaf was done in Pharmacology Laboratory, Faculty of Pharmacy. Rotatory evaporation process did in the Laboratory of Falitma, Universitas Gadjah Mada. Testing termites with 
the extraction was conducted at the Laboratory of Entomology, Faculty of Biology, Universitas Gadjah Mada.

\section{B. Leaf methanolic extract and determination}

The fresh papaya leaves were obtained from the garden community that located in Bantul district, Indonesia. This leaves were washed to remove contaminant and dried in a room without direct sunlight. Then, the completely dried leaves were blended. 200 grams of blended were used for extraction added $1000 \mathrm{ml}$ methanol for 6x24 hours in Erlenmeyer $1000 \mathrm{ml}$. Each three days, extract solution was filtered using filter paper and filled by $1000 \mathrm{ml}$ methanol. The filtered extract was evaporated using a rotary evaporator at $45^{\circ} \mathrm{C}$ in $60 \mathrm{rpm}$. Condensed extract were stored in a porcelain dish for maceration process. Total secondary metabolite content was determination using thin layer chromatography.

\section{Mortality test of termites}

Papaya leaf extract was taken with concentration of $6 \%$, $8 \%$, and $10 \% \mathrm{w} / \mathrm{v}(\mathrm{g} / \mathrm{ml})$. To make this concentration, used papaya leaf extract, in which 0.6 grams, 0.8 grams and 1 gram, then dissolved in $10 \mathrm{ml}$ of $10 \%$ DMSO (dimethylsulfoxide). Soil was taken from the Forest Biology, Faculty of Biology, Universitas Gadjah Mada, was sterilized using autoclave for 1 hour.

Three filter papers (Whatmann No. 41) with diameter of 4 $\mathrm{cm}$, soaked in leaf extract solution for 1 hour. Then, the filter paper was dried for 24 hours in room temperature. Two other papers were soaked in water and fibronil as control. The filter papers were weighed to determine the mass of paper. $10 \mathrm{~g}$ of soil was put in a plastic cup and $2 \mathrm{ml}$ of water dripped to soil. Circular filter paper (modified) placed on top of pedestal inside the plastic cup. Fifty termites comprising 45 soldier and five worker termites released into each cup. The plastic cup was placed in a dark room in 7 day, checked each day. Four replications were made for each treatment and control.

\section{Mortality termites observation}

Termites were observed in each day for all treatments and counted the number of dead termites. Percent mortality each treatment is calculated using formula [19]

$\mathrm{M}(\%)=\frac{\mathbb{N}_{2}}{\mathbb{N}_{1}} \times 100 \%$

where :

$\mathrm{M}$ is mortality percentage of termites (\%)

$\mathrm{N}_{1}$ is number of termites before treatment

$\mathrm{N}_{2}$ is number of termites after treatment

Test of the filter paper weight between before and after observation. Then calculate the weight loss filter paper with the following formula [19]

Weight loss $(\%)=\frac{W_{1}-W_{2}}{W_{1}} \times 100 \%$

where :

$\mathrm{W}_{1}$ is weight of filter paper before treatment $(\mathrm{g})$

$\mathrm{W}_{2}$ is weight of filter paper after treatment $(\mathrm{g})$

\section{E. Statistical Analyses}

The percentage of termite mortality and calculation of weight loss filter paper were analyzed by analysis of variants (ANOVA) with a 95\% confidence level. This analysis showed significantly different results, so continued use Duncan test. Then, the alleged death value of $50 \%\left(\mathrm{LC}_{50}\right)$ was determined using probit analysis by linear regression equation between $\log$ concentration and probit mortality.

\section{RESULT AND DISCUSSION}

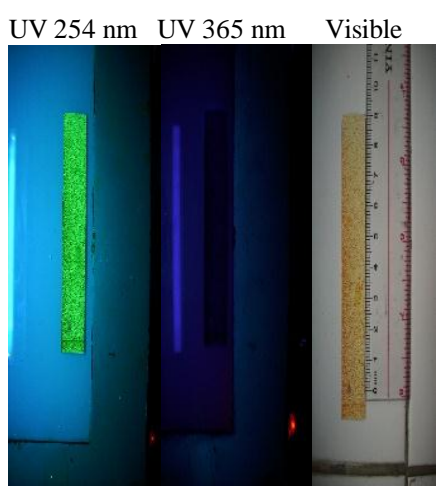

(a)

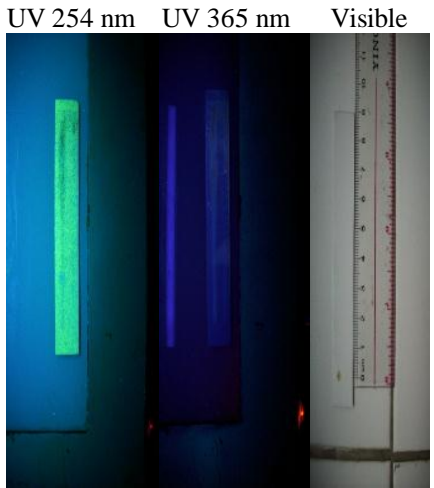

(c)

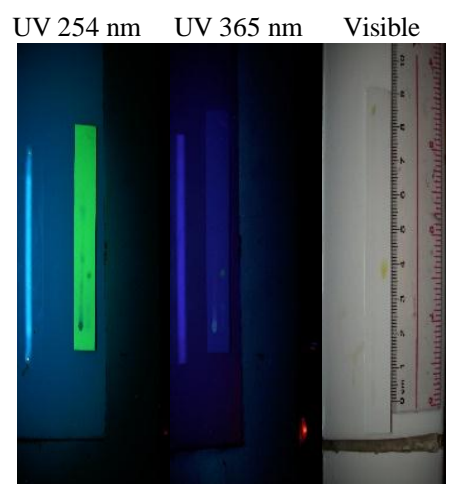

(b)

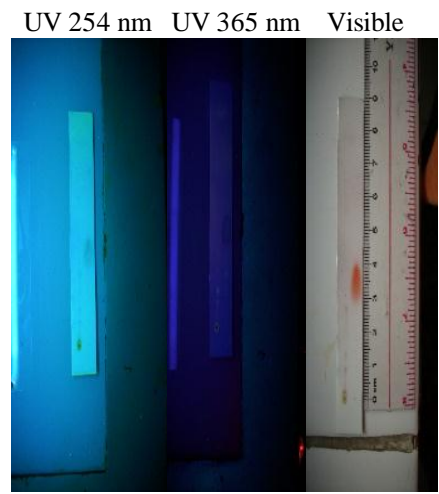

(d)
Fig 1. Chromatography test for Secondary metabolites compounds a) Alkaloids b) Flavonoids c) Saponins d) Terpenoid in Methanolic Extract Carica papaya

We analyzed the influence of methanolic extract $C$. papaya on termites mortality. Result testing shows and served on the table below.

\section{TABEL 1}

MORTALITY PERCENTAGE C. CURVIGNATHUS (\%), LOSE WEIGHT METHANOLIC EXTRACT OF C. PAPAYA (\%) IN SEVERAL CONCENTRATION IN 7 DAYS.

\begin{tabular}{llcl}
\hline \hline Treatment & $\begin{array}{c}\text { Mortality } \\
(\%)\end{array}$ & $\begin{array}{c}\text { Lose the } \\
\text { weight of the } \\
\text { paper test } \\
(\%)\end{array}$ & $\mathrm{LC}_{50}$ \\
\hline Solvent & $32,77^{\mathrm{a}}$ & 33,1 & \\
$6 \%$ & $73,88^{\mathrm{b}}$ & 41,57 & \\
$8 \%$ & $97,00^{\mathrm{b}}$ & 41,95 & $4,52 \%$ \\
$10 \%$ & $95,00^{\mathrm{b}}$ & 42,38 & \\
Termicide $0,5 \%$ & $98,88^{\mathrm{b}}$ & 45,58 & \\
Explanation: Number with same information $\left(^{\mathrm{a}}\right.$ or $\left.^{\mathrm{b}}\right)$ shows significance in $95 \%$ \\
confidence interval.
\end{tabular}


Based on the result of ANAVA testing, negative control (distilled water) was significantly different with the treatment in concentration $6 \%, 8 \%, 10 \%$ and termicides. The other way, concentration $6 \%, 8 \%$ and $10 \%$ were not significantly different with positive control (termicides). Probit analyze to determine Lethal Concentration $\left(\mathrm{LC}_{50}\right)$ used software SPSS 21.0. The result shows that using methanolic extract C. papaya againts $C$. curvignathus has $\mathrm{LC}_{50}$ at the concentration $4,25 \%$. On the graph below shows relation the number of mortality and consumption toward the decrease of the concentration.

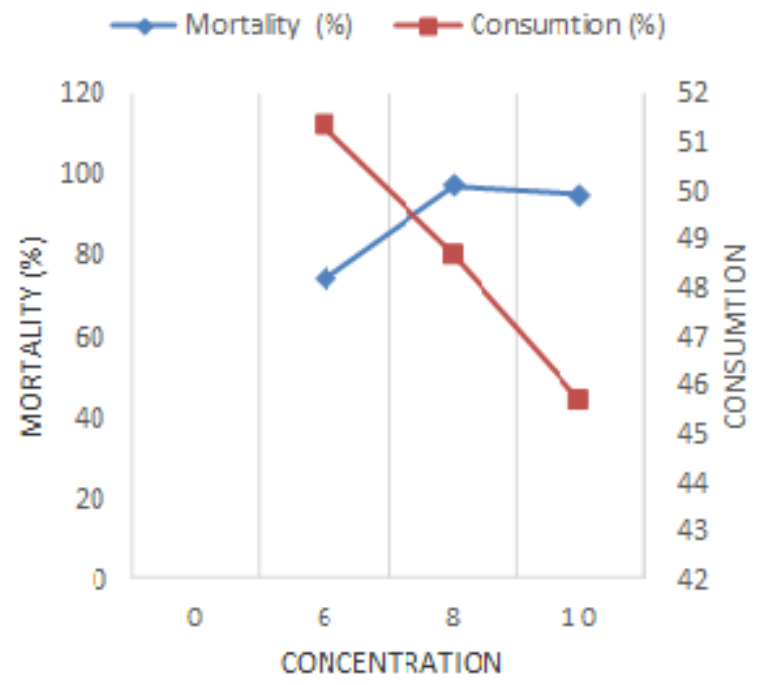

This research shows that different level concentration of methanolic extract papaya leaf influenced to mortality and number of consumption (Fig. 2). Mortality will be higher along with increasing the concentration and the consumption will be lower. It has related to the toxicity in papaya leaf. Plants produced a high diversity of natural products or secondary metabolites with a prominent function in the protection againts the predator. Secondary metabolites such as tannins, saponins, alkaloids, steroids, and terpenoid could cause death in termites and have potential as bioinsecticides. Secondary metabolites compound in papaya leaf was tested using Thin Layer Cromatography (TLC), and the result showed in Fig. 1. There are four main compound which have potential as bioinsecticides in papaya leaf such terpenoids, flavonoids, saponins, alkaloids. Each compound has capabilty as toxic in termites. Flavonoid compounds that have a polar nature is able to penetrate the peptidoglycan also have polar properties in bacterial cells that can cause damage to cells [20]. Flavonoids are cyto-toxic and interact with different enzyme through complexation. Falvonoids againts insect pest by influencing the behaviour and growth and development of insect. Phenolic compounds capable to forming a complex with the protein (constituent of cell membranes) trough hydrogen bonds. So, that toxic subtances from the extract get into the cells and attack the nucleus, and causing the nervous system disrupted.

Papaya leaf extract has terpenoids compound which have role as protector to resist insects as well as a stomach poison to insects [21]. Extractive substances bioactivity against termite death also influenced by the habits of termites like licking, delivering food from the caste of workers to other members of a colony of termites. Based on the research done, papaya leaf extract containing secondary metabolites have potential as biotermicide. The highest mortality reached $97 \%$ in testing time for 7 days and $\mathrm{LC}_{50}$ probit analysis obtained concentration $4,25 \%$, which means that is effective as termicides.

\section{CONCLUSION}

From this research, we can conclude that $C$. papaya extract leaf can use as biotermicide and $\mathrm{LC}_{50}$ in the concentration $4,25 \%$.

\section{ACKNOWLEDGEMENT}

We thank to these people and institution who gave contribute to this research:

Laboratory of Entomology and Biochemistry laboratory Faculty of Biology and Faculty of Pharmacy Universitas Gadjah Mada in determined secondary metabolites compound in papaya leaf. And we also thank to Nurria, who lead us to find $C$. curvigathus in her village Bantul, Yogyakarta.

\section{REFERENCES}

[1] Radhitya, Moch. Sabeth dan Zulfahmi.2010. Pemanfaatan Limbah Kulit Udang sebagai bahan Anti Rayap (Bio- Termisida) pada Bangunan Berbahan Kayu. Skripsi Susanta, Gatut. 2007. Cara Praktis Mencegah Dan Membasmi Rayap. Jakarta. Penebar swadaya. p. 3

[2] Wariyono, Sukis., Muharoma, Yani. 2008. Ilmu Alam Sekitar. Jakarta. Departemen Pendidikan Nasional. p.59

[3] Risza, Suyatno. 2012. Kelapa Sawit Upaya Peningkatan Produktivitas. Yogyakarta. Kanisius. p.99

[4] Hutabarat, N.K., Omrey, S., Pinem, M.I. 2015. Uji Efektivitas Termitisida Nabati Terhadap Mortaliatas Rayap (Coptotermes curvinagthus Holmgren) (Isoptera : Rhinotermitidae) di Laboratorium. Jurnal Online Agroekoteknologi. Vol.3, No.1 : 103- 111

[5] Avitable SC, Nimmo DG, Bennett Af, Clarke MF, Termites Are Resistant to the Effects of Fire at Multiple Spatial Scale. PLoS ONE , 2015, 10(11): $\mathrm{e} 0140114$.

[6] Hadi, Mochammad. 2008. Pembuatan Kertas Anti Rayap Ramah Lingkungan dengan Memanfaatkan Ekstrak Daun Kirinyuh (Eupatorium odoratum).Bioma. Vol. 6, No. 2, Hal. 12-18

[7] Eggleton, P., Tayasu, I., Feeding groups, lifetypes and the global ecology of termites. Ecological Research, , 2001, 16, 941-960.

[8] Basset, Y.,. The taxonomic composition of the arthropod fauna associated with an Australian rain-forest tree. Australian Journal of Zoology, 1991 ,(39), 171-190.

[9] Arkhiadi Benauli Tarigan, Maryani Cyccu Tobing, Syahrial Oemry.2015. Pengaruh Cordyceps militaris terhadap mortalitas rayap (Coptotermes curvignathus Holmgren) (Isoptera: Rhinotermitidae) di laboratorium. Jurnal Online Agroekoteknologi. Vol.3, No.3 : 1116 - 1122

[10] Nandika,D.,Y.Rismayandi,dan F.Diba, 2003. Rayap, Biologi dan Pengendalian. Surakarta. Muhammadiah University Press.

[11] Kartika et al. 2007. Pengembangan Formula Bahan Infeksi Cendawan sebagai Alternatif Biokontrol Rayap Tanah Coptotermes sp. J. Ilmu \& Teknologi Kayu Tropis Vol.5 No. 22007.

[12] Janet Hemingway and Hilary Ranson.. Insecticide Resistance in Insect Vectors of Human Disease, Annual Review of Entomology, 2000, Vol. (45):371-391

[13] Zulyusri, Desyanti, Usnal Mardia. 2013. Keefektifan Daun Sangitan (Sambucus javanica Reinw) Sebagai Insektisida Nabati dalam Pengendalian Rayap Tanah (Coptotermes sp.). Prosiding Semirata FMIPA Universitas Lampung. 521-52.

[14] Antonella Canini,Daniela Alesiani,Giuseppe,D'Arcangelo, Pietro,Tagliatesta, Gas chromatography-mass spectrometry analysis of 
phenolic compounds from Carica papaya L. leaf. Journal of Food Composition and Analysis, . 2007, (20) 584-590.

[15] Zalim, S.Z., Abdullah, N.R., Afzan, A., Rashid, B.A.A, Jantan, I., Ismail. 2010. Acute toxicity study of Carica papaya leaf extract in Sprague Dawley rats. Journal of Medicinal Plants Research Vol. 5(xx), pp. 18671872.

[16] Imaga NOA, Gbenle GO, Okochi VI, Akanbi SO, Edeoghon SO, Oigbochie V, Kehinde MO, Bamiro SB (2009). Antisickling property of Carica papaya leaf extract. Afr. J. Biochem. Res., 3(4): 102-106.

[17] Seigler DS, Pauli GF, Nahrstedt A, Leen R., Cyanogenic allosides and glucosides from Passiflora edulis and Carica papaya. Phytochemistry, 2002, (60):873-882

[18] Utomo, M, Amaliah, S, Suryati, Febria A. 2010. Daya Bunuh Bahan Nabati Serbuk Biji Papaya Terhadap Kematian Larva Aedes aegypti Isolat Laboratorium B2P2VRP Salatiga. Prosiding Seminar Nasional UNIMUS.

[19] Salam, DM, Murkalina, Diba F. 2014. Pengendalian Rayap Tanah Coptotermes curvignathus Holmgren Menggunakan Ekstrak Daun Gulma Sembung Rambat (Mikania micrantha Kunth). Jurnal Protobiont, 3(2): 8792.

[20] Carpenter,SJ, Lacasse, WJ. 1955. Mosquitoes of North America (North of Mexico). University of California. P. 360

[21] Brown, HW, Neva, FA. 1995. Basic Clinical Parasitology. 6 Edition PrenticeHall International Edition. 